\title{
新幹線の台車部から発生する空力音の実験的推定法
}

\author{
山崎 展博*1,*3, 北川 敏樹"1, 宇田 東樹*1, 栗田 健 ${ }^{* 2}$, 若林 雄介 ${ }^{* 2}$, 西浦 敬信 ${ }^{* 3}$
}

\section{Estimation methods for aerodynamic noise generated from the bogie section of Shinkansen trains by using wind tunnel test}

\author{
Nobuhiro YAMAZAKI ${ }^{* 1,33}$, Toshiki KITAGAWA*1, Toki UDA*1, Takeshi KURITA ${ }^{* 2}$, \\ Yusuke WAKABAYASHI ${ }^{* 2}$ and Takanobu NISHIURA*3 \\ ${ }^{* 1}$ Railway Technical Research Institute \\ 2-8-38 Hikaricho, Kokubunji-shi, Tokyo 185-8540, Japan \\ ${ }^{* 2}$ East Japan Railway Company, 2-479 Nisshincho, Kita-ku, Saitama-shi, Saitama 331-8513, Japan \\ ${ }^{* 3}$ Ritsumeikan Univ., 1-1-1 Nojihigashi, Kusatsu-shi, Shiga 525-8577, Japan
}

Received: 30 March 2017; Revised: 10 May 2017; Accepted: 6 June 2017

\begin{abstract}
A method has been developed for predicting the aerodynamic noise from the bogie of a high-speed train using a two-dimensional microphone array in a low-noise wind tunnel. First, the mean velocity distribution of flow was simulated precisely in the low-noise wind tunnel. Next, aerodynamic noise generated by the bogie, hereinafter referred to as aerodynamic bogie noise, was estimated from the noise source distribution measured with the two-dimensional microphone array. Finally, based on the experimental results, the predicted noise generated from the lower part of the car (i.e. the total of the aerodynamic noise estimated through the proposed method and the rolling and machinery noise estimated in a previous study) was compared with the measurement data obtained near the track in the field test. It was found that the predicted sound pressure level showed good agreement with those measured in the field test. This suggests that the proposed method is appropriate to estimate the aerodynamic bogie noise quantitatively. It was also shown that the contribution of the aerodynamic bogie noise to the total noise generated from the lower part of the car is greater than that of rolling and machinery noise, especially below $500 \mathrm{~Hz}$.
\end{abstract}

Key words : Aerodynamic noise, High speed train, Bogie, Wind tunnel test, Microphone array

\section{1. 緒言}

高速で走行する鉄道車両から発生する空力音は沿線環境問題の一つであり，長年その発生源や低減法に関する 研究が数多くおこなわれている（Kitagawa and Nagakura, 2000, Kurita, 2011, Thompson et al., 2015）。騷音の低減対 策を効率的に行うためには, まず騒音の発生源ならびにその寄与を把握することが重要となる（Mellet et al., 2006, Poisson et al, 2008). 新幹線騷音は主として，(1) パンタグラフ空力音，(2）先頭部空力音，(3）車両上部空力音,

（4）構造物音，（5）本両下部から発生する騷音（以下，車両下部音）から構成されている（長倉, 善田, 1996). 沿線での新幹線騒音は時間重み付け特性 S の A 特性音圧レベルの最大レベルで評価されるが, 新幹線沿線騒音の 標準的な測定点である地上 $25 \mathrm{~m}$ 点での音源寄与度は, 最新の新幹線が現状の営業速度よりも高速で走行する場合, 防音壁が設置された区間において主に車両下部音の占める寄与が大きいことが示されている (Kurita et al., 2011). また最大レベルに対する(1)〜(5)の音源の寄与について, 10 両以上の車両が連結されている編成では, 車両先頭 部や 1 編成中に搭載されている数が 2 基程度であるパンタグラフ空力音に比べて, 車両下部音が大きくなると推

\footnotetext{
No.17-00146 [DOI:10.1299/transjsme.17-00146], J-STAGE Advance Publication date : 20 June, 2017

*1 正員，（公財） 鉄道総合技術研究所（干185-8540 東京都国分寺市光町 2-8-38）

*2 正員，（株）東日本旅客鉄道（テ331-8513 埼玉県さいたま市北区日進町 2-479）

*3 立命館大学 情報理工学研究科（广525-8577 滋賀県草津市野路東 1-1-1）

E-mail of corresponding author: yamazaki.nobuhiro.42@rtri.or.jp
} 
定されている (Kurita et al., 2011)。このため今後の新幹線騷音の低減に向けて，中間車両下部音に対する対策が 重要であると考えられる.

車両下部音の代表的な発生要因としては転動音, 空力音が挙げられる. このうち転動音については, レールお よび車輪等の振動に基づく理論的考察により定量的な推定結果が報告されている（北川他, 2013）。一方空力音に ついは，台車部から発生する空力音（以下，台車部空力音）や車両間間隙部下部から生じる空力音等が考えら れる. 特に車両下部の台車装置を格納する空間 (以下, キャビティ) 内には複雑な形状の機器が格納されており, 流れの乱れを誘起する不整部が多く存在するため, 車両下部音の主たる騒音源の一つと考えられる. キャビティ 部から発生する空力音に関しては新幹線のみならず航空機の主脚格納部等にも見られる構造であり, 古くから工 学的関心も高くその理論的研究が行われている（横山, 加藤, 2009). また台車部空力音の評価を目的とした研究 例として, 風洞実験ならびに数値シミュレーションによる方法が報告されている（Masson et al., 2011, 森田他, 2006）。しかし従来研究においては, 車両と地面との間の相対運動の影響により台車部に流入寸る流れ場の状態に 不明な点が多いこと，また台車に取り付けられた車輪や主電動機等複雑な形状の装置が与える影響について詳細 な知見が得られていないことから，台車部空力音については未だ定量的な推定が行われていない.

台車部空力音の発生は台車部に流入する平均流速や乱れ度と密接に関連する。このうち平均流速については, 実際に走行する新幹線のスラブ軌道上に流速計をまくらぎ方向に配置し車両通過時の速度を測定することで，レ 一ル方向の平均流速成分のまくらぎ方向分布が明らかにされている (岩㠃他, 2015, 宇田他, 2015). これによれば, 先頭車両の後位台車（以下，先頭車）および概ね 3 両目以降の台車部（以下，中間車）においては，台車部流入 箇所における車両中心から車両側方に至るまでのまくらぎ方向分布が先頭車と比較して定量的に異なること, 中 間車ではまくらぎ方向に対する車両中心付近における車両側からみた車両床下流速が，列車走行速度の半分程度 に減速していることが示されている，これらの知見は，台車部空力音を評価する風洞実験や数值計算において台 車部に流入する流速の条件として有用である.

そこで本研究では，実際の新幹線軌道上で得られた台車部流入速度特性を模擬する風洞試験手法および新幹線 編成の中間部に位置する台車部空力音の定量的評価を行う手法を検討した。第一段階として, 先頭車ならびに中 間車の台車部流入箇所における平均流速のまくらぎ方向分布を風洞試験で模擬する手法について検討を行った. 次に, 騒音測定精度を向上させるために二次元マイクロホンアレイ（以下，アレイ装置）を活用し，台車部空力 音を定量的に推定する手法を提案した. 最後に本推定手法の妥当性を検証するため, 風洞試験による推定結果と 現地での試験結果との比較を行った。

\section{2. 風洞試験による車両下部流速分布調整法}

\section{$2 \cdot 1$ 風洞試験の概要}

台車部流入箇所における流速分布の模擬, ならびに台車部空力音の測定を目的とした風洞試験を, 公益財団法 人鉄道総合技術研究所が所有する大型低騒音風洞で実施した. 風洞試験での供試体および測定装置の設置状況を 図 1 に示す. $x, z$ 軸はそれぞれ主流方向および鉛直上方向, $y$ 軸はこれらに直交する向きとする. $x, y, z$ の各座標 系の原点はそれぞれ台車部中心，ノズル中心および地面板表面高さである. 車両模型は, ステージ $y$ 方向幅 5500 $\mathrm{mm}, x$ 方向長さ $7000 \mathrm{~mm}$ ) の上に設置されたアルミ製地面板 $(y$ 方向幅 $1100 \mathrm{~mm}, x$ 方向長さ $5300 \mathrm{~mm}$, 厚さ 15 $\mathrm{mm}$ ）に支持脚を介して設置されている. これらのステージ，地面板，車両模型およびノズルの $y$ 方向中心は同 一線上に位置する. 車両模型は現車スケールの $1 / 7$ 縮尺であり, 先頭側から $1+0.5$ 両の計 1.5 両編成で構成され ており，本試験においては車両模型中央付近に模擬した台車部を測定対象とする.なお今回の風洞試験では台車 部空力音が測定対象であるため, 上流側および下流側車両模型の車間部の全周を覆った状態とした．車両模型の 先端部はノズル吹き出し口から $750 \mathrm{~mm}$ 下流となるように設置した. この場合の測定対象台車部中心のノズル端 部からの $x$ 方向距離は $3750 \mathrm{~mm}$ となる. また, 車両模型の支持脚は, 車両模型の先頭側および後尾側端部からそ れぞれ $500 \mathrm{~mm}$ の位置に設置する. また台車部側方に設置するアレイ装置に対して車両模型先頭部や支持脚から 発生する騒音の影響を小さくするため，車体先頭部付近の側方に遮音板を設置した．

風洞試験では, 図 2 に示寸通り実際の台車形状を精密に模擬した台車装置を使用した。またその設置位置は, 車両下部に設けた $x$ 方向長さ $571.4 \mathrm{~mm}$ (現車スケール $4000 \mathrm{~mm}$ ), $y$ 方向幅 $400 \mathrm{~mm}$ (現車スケール $2800 \mathrm{~mm}$ ), $z$ 
方向高さ $114 \mathrm{~mm}$ (現車スケール $798 \mathrm{~mm}$ ) のキャビティ内に格納されている. 風洞試験で検討した台車条件を図 3(a)〜図 3(d)に示す. 条件 $\mathrm{A} \sim \mathrm{C}$ はいずれも台車装置を搭載した条件で，側カバーの形状をフルカバー，ハーフカ バー，カバー無としたものである．特に条件 A は，近年の新幹線車両で採用されている低騒音化対策として，台 車装置の両側が車体下面高さまで側力バーで覆われた状態となっている. 条件 D は台車装置を取り外したうえで キャビティの側方および底部を完全に覆った条件であり，この条件を騒音測定時の暗騒音条件とする，なお，台 車装置模型には, 図 2 に示す通り 4 箇所の軸箱部に脱線防止用 L 型ガイドを模擬した突起が取り付けられている.

台車部流入箇所におけるまくらぎ方向流速分布を測定するため，図 4 に示す通り車両模型下部に総圧管をま くらぎ方向に配置した. なお，本報告で記載する流速值の結果はいずれも平均流速のレール方向成分を指すこ ととする．総圧管の孔口の位置は $x=-476 \mathrm{~mm}$ (現車スケールで台車部キャビティ中心から $3332 \mathrm{~mm}$ 上流側） に位置している.また車体模型下部の $x=-393 \mathrm{~mm}, y=80 \mathrm{~mm}$ の位置に静圧孔を設けた。送風条件下における 総圧孔ならびに静圧孔からの圧力を多点圧力計（PSI 社製 ESP-32HD,レンジェ6.89 kPa）で計測した。この際の サンプリング周波数は $9.77 \mathrm{~Hz}$ ，データ点数は(150 点×64 回平均) である.これらの圧力值により式 (1) に従 い無次元流速 $u_{n}$ （ $n$ は図 4(b)に示すセンサ番号）を算出した.

$$
u_{n}=\sqrt{2\left(p_{n}-p_{0}\right) / \rho} / U_{\infty}
$$

ここで $p_{n}, p_{0}$ はそれぞれ図 4 に示す各総圧孔および静圧孔で得られた圧力， $\rho$ は空気密度である.また $U_{\infty}$ はノズ ル吐出部に設置したピトー管による流速值であり，本試験では，新幹線の営業最大速度から $U_{\infty}=320 \mathrm{~km} / \mathrm{h}$ と

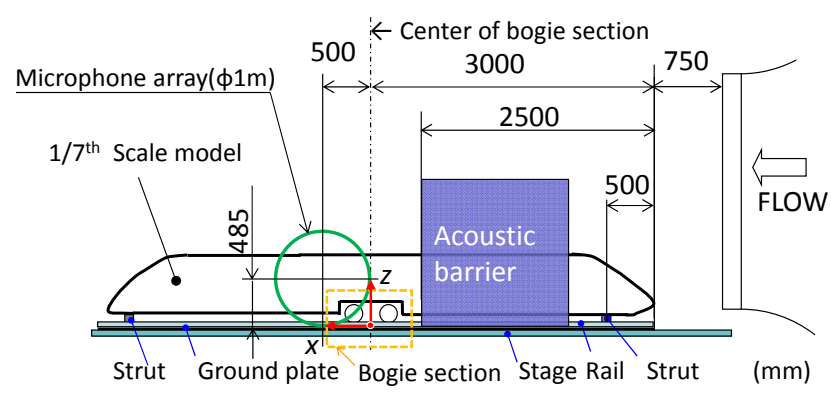

(a) Side view

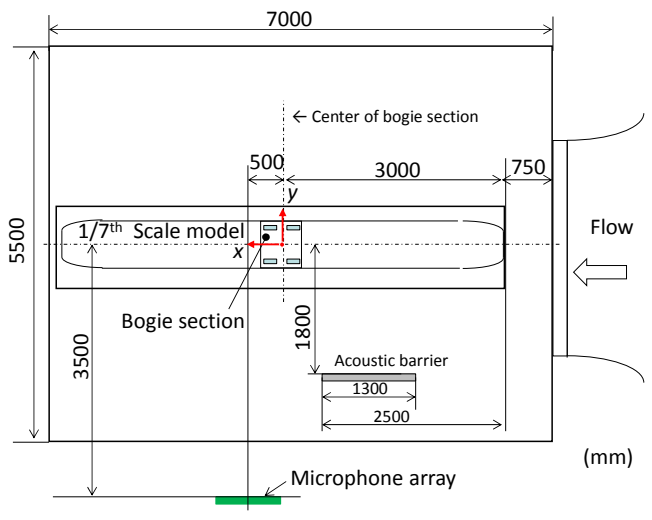

(b) Plane view

Fig. 1 Schematic layout of the wind tunnel test. $1 / 7^{\text {th }}$ scale train model is installed in an anechoic room of the open test section. Aerodynamic bogie noise is measured by 2-D microphone array located at the side of the train model.

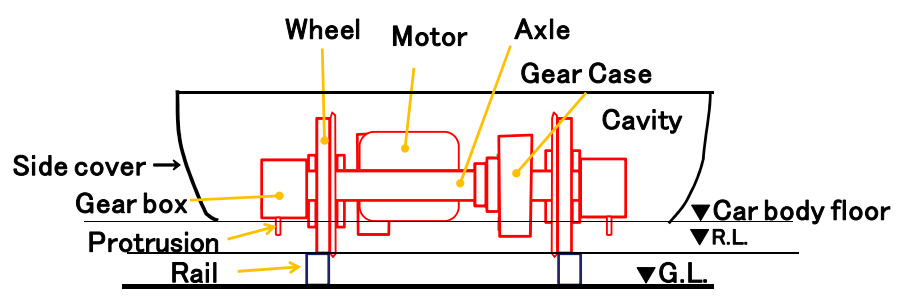

Fig. 2 Cross view of the bogie section modeled in the wind tunnel test. Main parts are precisely modeled.

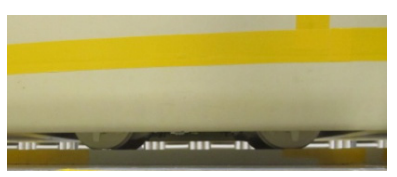

(a) Bogie condition $\mathrm{A}$ Bogie with full side covers

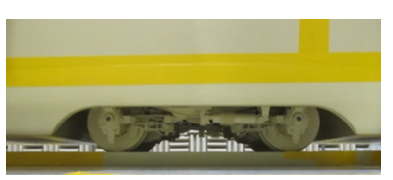

(b) Bogie condition B Bogie with half side covers

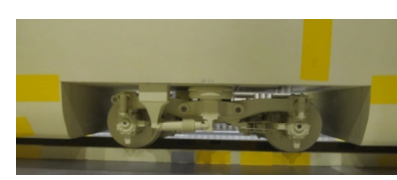

(c) Bogie condition $\mathrm{C}$ Bogie without side covers

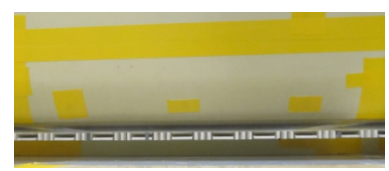

(d) Bogie condition D Flat condition

Fig. 3 Bogie conditions for noise measurement. Both sides of the bogies are covered in Cases A and B, while the side covers are removed in Case C. Both sides and bottom of the cavity are completely covered in Case D (back ground noise condition). 


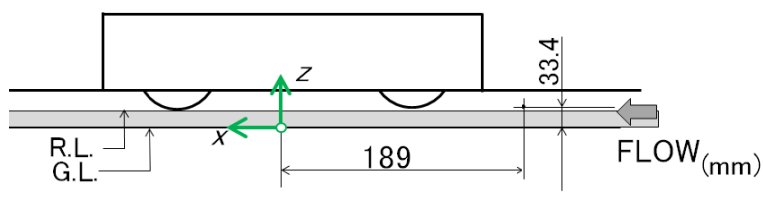

(a) Side view

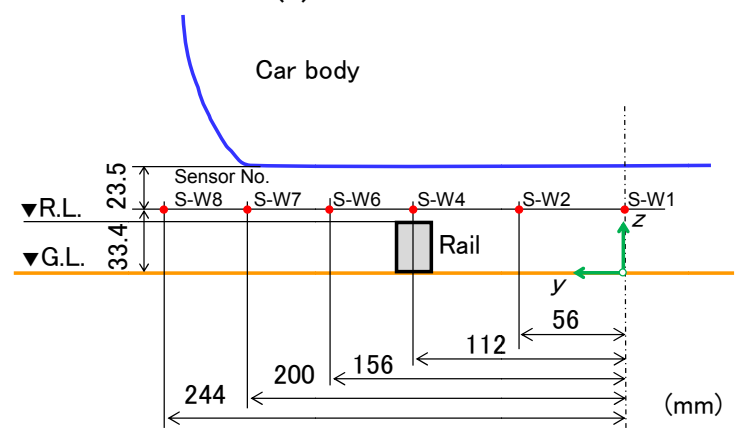

(b) Front view

Fig. 4 Velocity measurement points under the train car in front of the bogie section in the wind tunnel test.

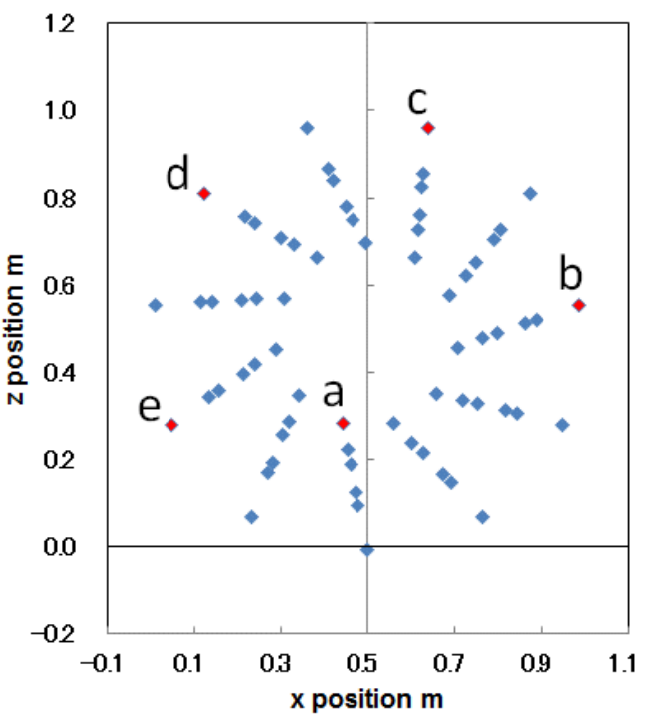

Fig. 5 Positions of 66 microphones in the wheel shaped 2-D microphone array. a-e denote the microphones referred in Fig.12 showing the signal to noise ratio. $\mathrm{a}$ is the reference microphone in eq.(8)

した．なお本報告では全ての流速值は車両側から見た場合の值を示す．台車部空力騒音の測定に用いたアレイ装 置は, 図 5 に示寸通り直径 $1 \mathrm{~m}$ の範囲内に 66 本のマイクロホンがホイール状に配置されており, 現車スケール で $2 \mathrm{kHz}$ 帯までの音圧レベル分布の計測が可能である. アレイ装置はその中心座標が $x=500 \mathrm{~mm}, y=-3500 \mathrm{~mm}$, $z=485 \mathrm{~mm}$ となるように設置した. なお図中の $\mathrm{a} \sim \mathrm{e}$ は，後述するアレイ装置と無指向性マイクロホンとの信号対 杂隹音比を検討する際に参照したマイクロホンである.

\section{$2 \cdot 2$ まくらぎ方向に対する台車部流入速度分布の調整法}

風洞試験における台車部流入箇所での流速を調整に際しては，本研究の目的が台車部空力音の騷音測定である ことから, 流速調整機構自体により暗騒音レベルを増大させないように留意する必要がある. 以下に, 本研究で 提案する 2 種類の流速分布調整法を示す.

・流速分布調整法 1 ノズルまわりの自由せん断層を活用する方法

開放型測定部においては，図 6(a)に示す通りノズルまわりに自由せん断層が存在しており，主流内部から外部 に至るまでの領域で速度勾配が生じる．本手法ではこの速度勾配領域に着目し，ノズル底面とステージとの $\mathrm{z}$ 方 向間隔 $H$ (寸法は模型スケールで記載）を変化させることにより，自由せん断層内における台車部流入箇所の位 置を調整する.

Table 1 Velocity measurement positions under the train car

\begin{tabular}{|c|c|c|c|c|c|}
\hline \multicolumn{3}{|c|}{ Field test } & \multicolumn{3}{|c|}{ Wind tunnel test } \\
\hline & \multicolumn{2}{|c|}{ Sensor positions $*(\mathrm{~mm}) *$ Full scale } & \multirow{2}{*}{ Sensor No. } & \multicolumn{2}{|c|}{ Sensor positions $y^{*}(\mathrm{~mm}) *$ Full scale } \\
\hline & Lateral position & Vertical position & & Lateral position ( $1 / 7$ Scale) & Vertical position \\
\hline S-F1 & -2.5 & \multirow{8}{*}{185} & S-W1 & 0 & \multirow{8}{*}{234} \\
\hline S-F2 & 380.5 & & S-W2 & $392(56)$ & \\
\hline S-F3 & 584.5 & & 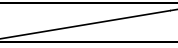 & 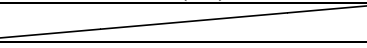 & \\
\hline 2 & 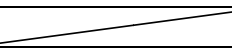 & & S-W4 & $784(112)$ & \\
\hline S-F5 & 909.5 & & 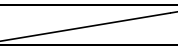 & (2) & \\
\hline S-F6 & 1093.5 & & S-W6 & $1092(156)$ & \\
\hline S-F7 & 1402.5 & & S-W7 & $1400(200)$ & \\
\hline S-F8 & 1710.5 & & S-W8 & $1708(244)$ & \\
\hline
\end{tabular}




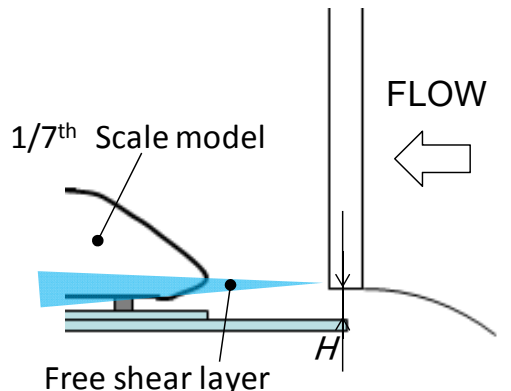

Free shear layer

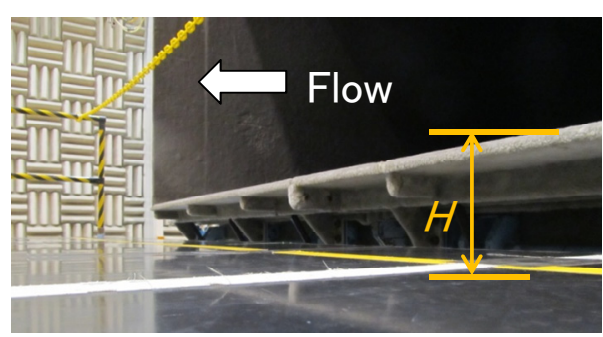

(a) Velocity adjustment method 1 using free shear layer. Velocity distribution is adjusted by changing the interval of the nozzle floor and the ground level.
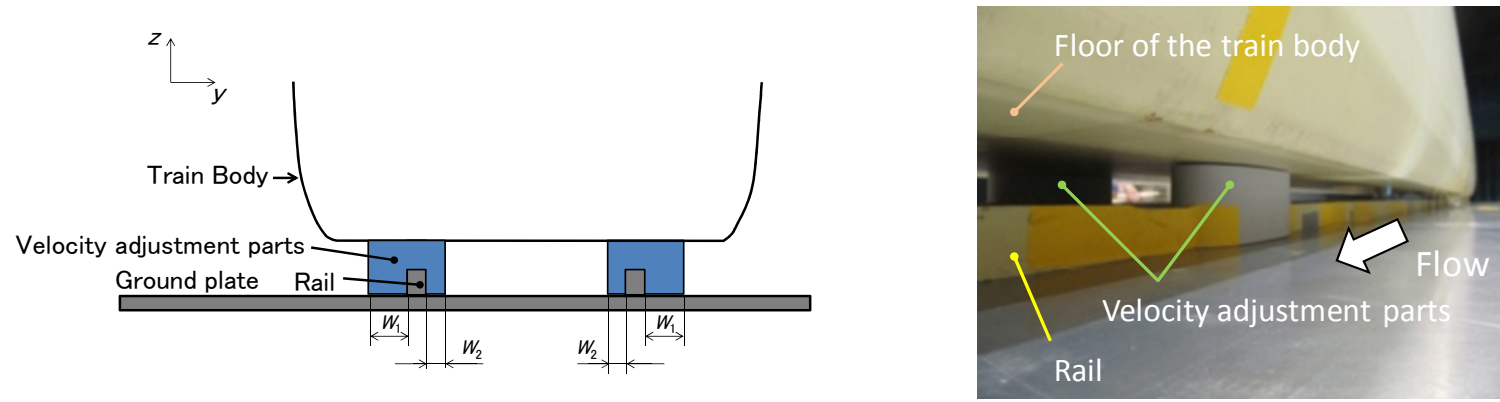

(b) Velocity adjustment method 2 using columnar parts on the rail. Velocity distribution is adjusted by changing the width of the parts.

Fig. 6 Adjustment methods for the flow velocity distribution along the sleeper direction.

・流速分布調整法 $2:$ 車両下部に部材を設置する方法

図 6(b)に示寸通り，柱状の部材を台車部の上流域における車両下部に取り付け，部材の幅 $W_{1}, W_{2}$ を $20 \mathrm{~mm}$ お よび $40 \mathrm{~mm}$ に変化させることで部材の後流域に生じる速度欠損領域を調整する．なお，ノズル底面とステージと の間隔は $H=0 \mathrm{~mm}$ とする.

現地試験結果との比較を行うため，文献（宇田 他, 2015）で示された現地測定データに基づき，スラブ軌道上 でまくらぎ方向に設置した熱線流速計により車両通過時の平均流速（レール方向速度成分）を測定した結果を参 照した．現地試験での流速測定点座標を，風洞試験での流速測定点の対応と合わせて表 1 に示寸．現地試験結果 で解析対象とした列車は，車体長約 $25 \mathrm{~m}$ ，車体幅約 $3.4 \mathrm{~m}$ の車両が 10 両編成で運行されている車両（以下 $\mathrm{A}$ 系 車両）である. 以下，1 両目の前位台車後端から後位台車前端までの車体下部通過時における無次元化平均流速 を先頭車流速分布，同じく 5 両目の同一区間における無次元化平均流速を中間車流速分布とする. 解析列車本数 は 11 本，列車速度は $270 \sim 317 \mathrm{~km} / \mathrm{h}$ である.

\section{$2 \cdot 3$ まくらぎ方向に対する台車部流入速度分布の調整結果}

流速分布調整法 1 によりノズル下面とステージとの鉛直方向間隔 $H$ を変化させた場合の流速分布を図 7 に示す. $H$ を 145 205 mm の範囲で変化させることにより $y=0 \mathrm{~mm}$ における無次元平均流速を $0.5 \sim 0.7$ に調整すること が可能である. また $H>175 \mathrm{~mm}$ の範囲では車両中心から車両端部方向に離れるにつれて概ね流速が単調に増加 する傾向を示す. 次に流速分布調整法 2 により, 部材の幅 $W_{1}, W_{2}$ を変化させた場合の平均流速分布を図 8 に示 す．部材を設置しない条件では，車両中心付近および車両端部に比べてレール位置付近で平均流速が低減し，ま くらぎ方向に対して凹型の分布を示す.これに対し $W_{1}=20 \mathrm{~mm}, W_{2}=40 \mathrm{~mm}$ および $W_{1}=W_{2}=20 \mathrm{~mm}$ の条件では 車両中心からレール間での平均流速が低減する。これは，車両中心付近では拡幅部材の後流域で速度が低減する 一方で，レールから車両端部にかけては車両の周りを流れる一様流が下部に流れ込むことによる影響を受けてい るためと考えられる.

これらの方法を用いて現地試験で得られた流速分布の模擬を行う. 先頭車流速分布と中間車流速分布をそれぞ れ風洞試験で流速調整法 2 および流速調整法 1 で模擬した結果をそれぞれ図 9(a), (b)に示寸.ここで現地試験結果

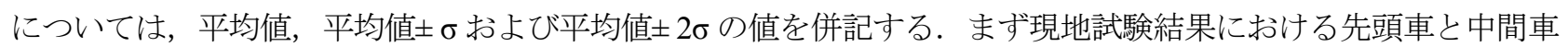


Yamazaki, Kitagawa, Uda, Kurita, Wakabayashi and Nishiura,

Transactions of the JSME (in Japanese), Vol.83, No.851 (2017)

の流速分布を比較すると，先頭車では車両中心から車両端部に至るまでに一度レール位置付近で流速が低減して おり，全体的には凹型の分布を示す。これに対し中間車ではまくらぎ方向に対して車両端部に向かい単調に平均 流速が増加する傾向を示す. また先頭車と比べて中間車では無次元平均流速は車両中心付近で約 0.3 , 車両端部付 近で約 0.1 小さくなる. 次に現地試験での先頭車流速分布と流速調整法 2 による調整結果の比較を図 9(a)に示す. まくらぎ方向に対する凹型形状の流速分布特性については調整部材無あるいは $W_{1}=W_{2}=20 \mathrm{~mm}$ とた場合の特 性と近い傾向を示す。一方中間車については，風洞試験における車両先端部から当該台車部までのレール方向距 離が現車よりも短いためさらに流速を低減させる必要があり, 流速分布調整法 1 で $H=175 \mathrm{~mm}$ とすることで現 地試験結果を模擬できることが確認できる. 以上の結果を踏まえ, 次節の台車部空力音の推定に際しては, 先頭 車については流速分布調整法 2 で $W_{1}=W_{2}=20 \mathrm{~mm}$, 中間車については流速分布調整法 1 での $H=175 \mathrm{~mm}$ とた 流れ場の条件で評価する.

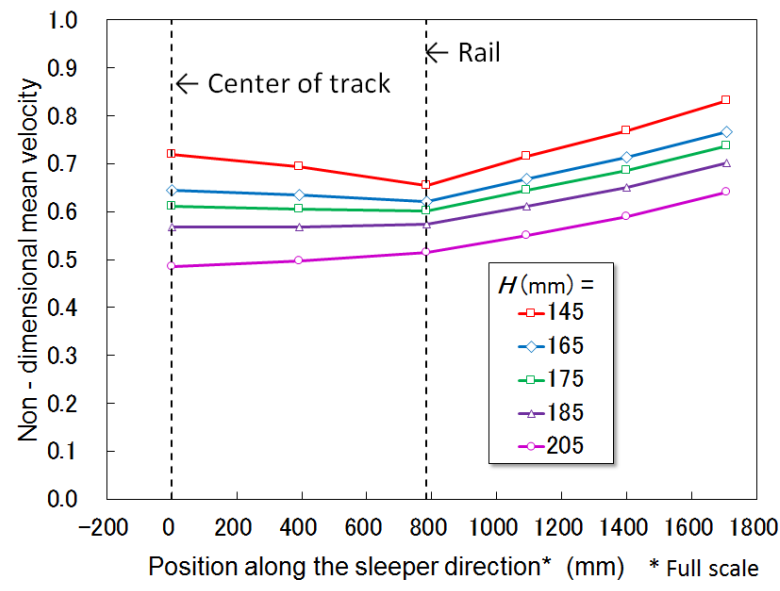

Fig. 7 Effect of bogie position inside the free shear layer on the flow velocity distribution along the sleeper directions. As the distance between nozzle floor and the stage is longer, the flow velocity is lower.

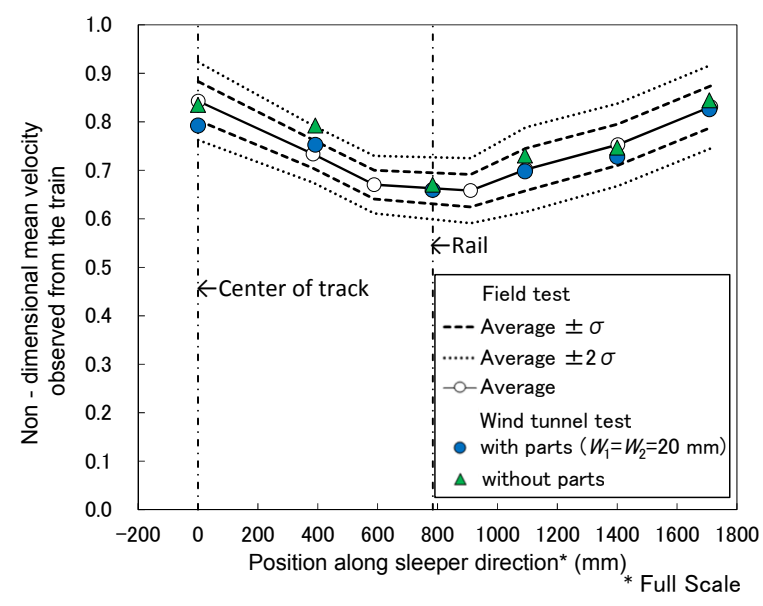

(a) Leading car (Method 2)

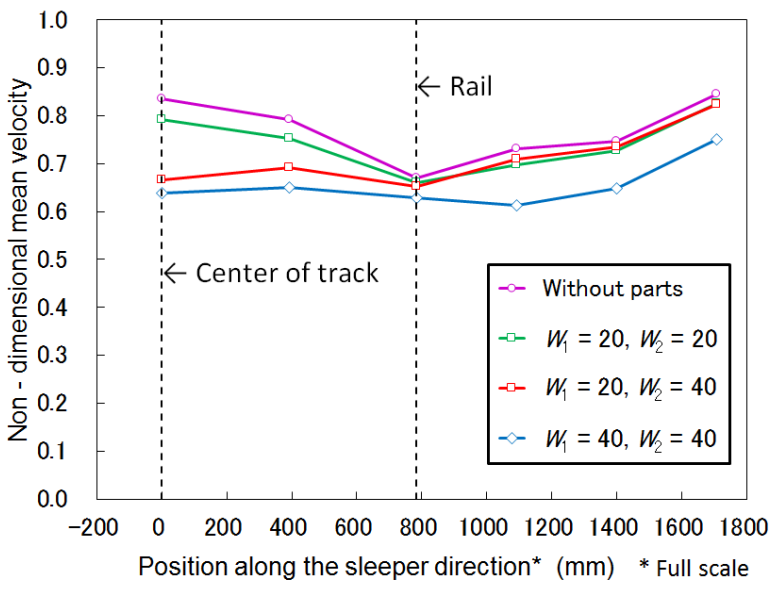

Fig. 8 Effect of the widths $\left(W_{1}, W_{2}\right)$ of velocity adjustments parts on the flow velocity distribution along the sleeper directions. As the widths of the parts are wider, the flow velocity within the range of 0 to $800 \mathrm{~mm}$ is lower.

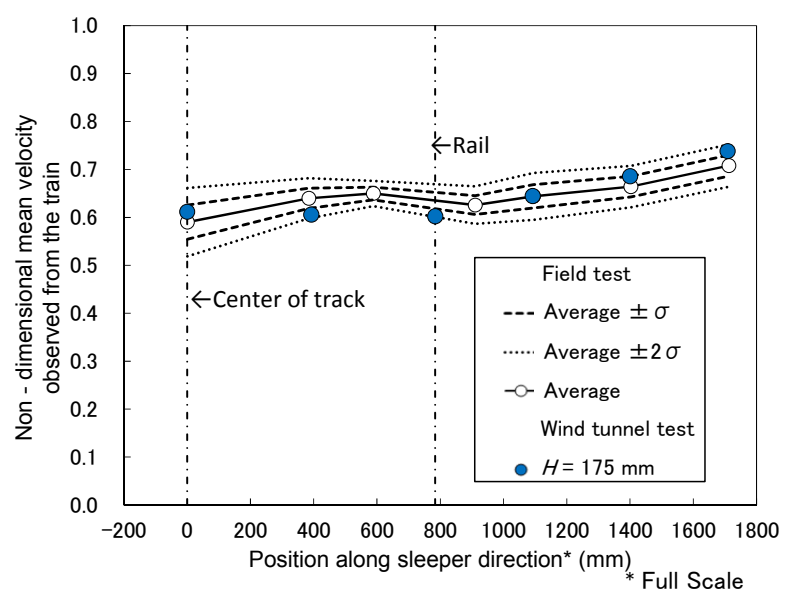

(b) Middle car (Method 1)

Fig. 9 Velocity distribution along the sleeper direction observed from the train. Each distribution of leading and middle car is adjusted. 


\section{3. 風洞試験による台車部空力音推定手法}

\section{$3 \cdot 1$ 台車部空力音推定手法の概要}

本節では風洞試験で台車部空力音を推定するために, アレイ装置により測定した音圧レベル分布に基づく騷音 レベル算出法について述べる.

(1) Delay and Sum 法に基づくビームフォーミング法(Flanagan et al., 1985 ) により，台車部のまわりでアレイ装置 による音圧レベル分布 $L_{B F}\left(f, x_{\mathrm{s}}, z_{s}\right.$, )を式（2），(3）により求める(Mueller, 2002).

$$
\begin{aligned}
& L_{B F}\left(f, x_{s}, z_{s}\right)=10 \log _{10}\left(\left[\sum_{m \neq m^{\prime}} X_{m} X_{m^{\prime}}^{*}\right]\right) \\
& X_{m}=\frac{1}{N} S_{m}(f) e^{\left(i k r_{m}\right)} r_{m} / r_{0}
\end{aligned}
$$

ここで $x_{s}, z_{s}$ は後述するビームフォーミングの解析格子点上の照準点座標， $f$ は現車スケールに換算した $1 / 3$ オクターブバンド周波数である. また $S_{m}(f)$ は $m$ 番目のマイクロホンで観測された音圧波形に対して短時間 FFT 処理により求めたスペクトル， $k$ は波数， $r_{m}$ は $m$ 番目のマイクロホンから解析平面上における照準点 $\left(x_{s}\right.$, $z_{s}$ )までの距離, $r_{0}$ はマイクロホンアレイから解析平面までの $y$ 軸方向距離, *は複素共役を示寸. なお(2)式中 の[ ]はアンサンブル平均を表し，対角項に相当する同一マイクロホン $\left(m=m^{\prime}\right)$ の成分を除くことで，風洞測 定部における風切り音のような各マイクロホン間で無相関な雑音成分の低減を図っている.

（2）台車部まわりに設定した領域 $S$ 内での指向性積分音圧レベル $L_{\text {inn }}(f)$ を式 (4) により算出する.

$$
L_{\text {int }}(f)=10 \log _{10}\left(\sum_{x_{s}, z_{s} \in S} 10^{\left(L_{B F}\left(f, x_{s}, z_{s}\right) / 10\right)}\right)
$$

（3）空力音の評価対象とする台車条件について，式（5)，（6）に基づき指向性積分音圧レベルと換算係数との差 により風洞試験で得られる台車部空力音の推定音圧レベル $L_{e s, W}$ を算出する.

$$
L_{e s t, W}(f)=10 \log _{10}\left(10^{\alpha}-10^{\beta}\right)
$$

$\alpha=\left\{L_{\text {int }}^{\text {Bogie }}(f)-C(f)+A_{w}(f)\right\} / 10, \quad \beta=\left\{L_{\text {int }}^{B G N}(f)-C(f)+A_{w}(f)\right\} / 10$

ここで $L_{\text {int }}$ の上添え字 Bogie は図 3(a)〜(c)に示寸各台車条件, $B G N$ は図 3(d)に示寸条件 D での平滑条件で得 られた指向性積分音圧レベルを示す. $A_{w}$ は周波数重み付け特性 $\mathrm{A}$ を示す. また $C(f)$ は指向性積分音圧レベ ルから風洞測定部での評価点における音圧レベルを算出する際の換算係数である. マイクロホンアレイの指 向特性に依存する換算係数を算出寸る際の条件については 4.2 項に後述する.

（4）風洞試験による台車部空力音の推定値 $L_{e s t, W}$ を現地試験で測定される音圧レベルに換算する. 現地試験におけ る車両下部音の代表的な測定点であるレール近傍測定点 $N$ ならびに, 本風洞試験における台車部空力音測定 点との位置関係を図 10 に示す．風洞試験では $1 / 7$ 縮尺模型から放射される空力音を $y=-3500 \mathrm{~mm}$ の位置で アレイ装置によって測定しているため，その地点で計測された音圧レベルは現車スケールで軌道中心から $24.5 \mathrm{~m}$ 側方に離れた位置での值に相当する．そこで，音源を点音源と仮定すると測定点 $N$ における音圧レベ ル $L_{e s t, F}$ を式（7）により推定できる.

$$
L_{e s t, F}(f)=L_{e s t, W}(f)+20 \log _{10}\left(\alpha r_{0} / r_{\mathrm{s}}\right)+10 \log _{10}(n)=L_{e s t, W}(f)+22
$$

ここで $1 / \alpha$ は模型スケールの縮尺比， $n$ は編成車両の 1 車間部付近に搭載されている台車の数であり, 本報 告では $\alpha=7, n=2$ となる. また $r_{s}$ は現車スケールにおける車両中心からレール近傍測定点までの $y$ 方向距離 (2.72 m) である. 


\section{$3 \cdot 2$ 指向性積分音圧レベルの換算係数}

式(6)に示寸換算係数 $C(f)$ については式(8)により算出した.

$$
C(f)=10 \log _{10}\left\{10^{\left(L_{\text {itt }}^{S t}(f) / 10\right)}-10^{\left(L_{\text {int }}^{\text {BGN }}(f) / 10\right)}\right\}-10 \log _{10}\left\{10^{\left(L_{\text {ommi }}^{S t}(f) / 10\right)}-10^{\left(L_{\text {ommi }}^{\text {BGN }}(f) / 10\right)}\right\}
$$

ここで $L_{\text {int }}^{S t}(f)$ および $L_{o m n i}^{S t}(f)$ は同一の台車条件で観測されたアレイ装置による指向性積分音圧レベルならび に台車部空力音を推定する位置での無指向性マイクロホンによる測定音圧レベルである．無指向性マイクロホン の位置に関する選び方について説明する. 図 10 中に示寸軌道断面図において, まくらぎ方向中心における車体下 面高さを音源位置 $S$ と仮定する．また前述したとおり，風洞試験での車両中心とアレイ装置の設置位置は，現地 スケールで $7 \times 3.5 \mathrm{~m}=24.5 \mathrm{~m}$ 側方に相当する.この場合地点 $S$ からレール近傍騒音測定点 $N$ を結ぶ延長線上の 24.5 $\mathrm{m}$ 離孔に対応する点 $M$ の $\mathrm{z}$ 座標は約 $2 \mathrm{~m}$ となる. そこで, 風洞試験で使用したアレイ装置を構成する個々のマイ クロホンの中で図 5 に示寸 $\mathrm{a}$ のマイクロホンを参照した，なお，換算係数を求める際の台車条件は無指向性マイ クロホンでも暗騒音レベルと十分な $\mathrm{S} / \mathrm{N}$ が確保されている必要がある. 本来はリファレンスとなる音源を用いて $C(f)$ を算出することが望ましいが，音源の特性は風洞試験での送風条件下における台車部空力音と異なるものと 考えられる. そこで本実験では, 条件 B との音圧レベル差が $3 \mathrm{~dB}$ 以上確保されている先頭車流れ場模擬時におけ る台車条件 Cでの測定音圧レベルを採用した。

\section{$3 \cdot 3$ 音圧レベル分布の計算条件}

ビームフォーミング演算時の計算条件を表 2 に示寸. 音圧レベル分布図の解析平面は $y=0$ における $x-z$ 平面 とした. 式（3）の行路 $r_{m}$ を算出する際には, 台車部からの放射音が主流内で移流する際の補正を行った(Amiet,

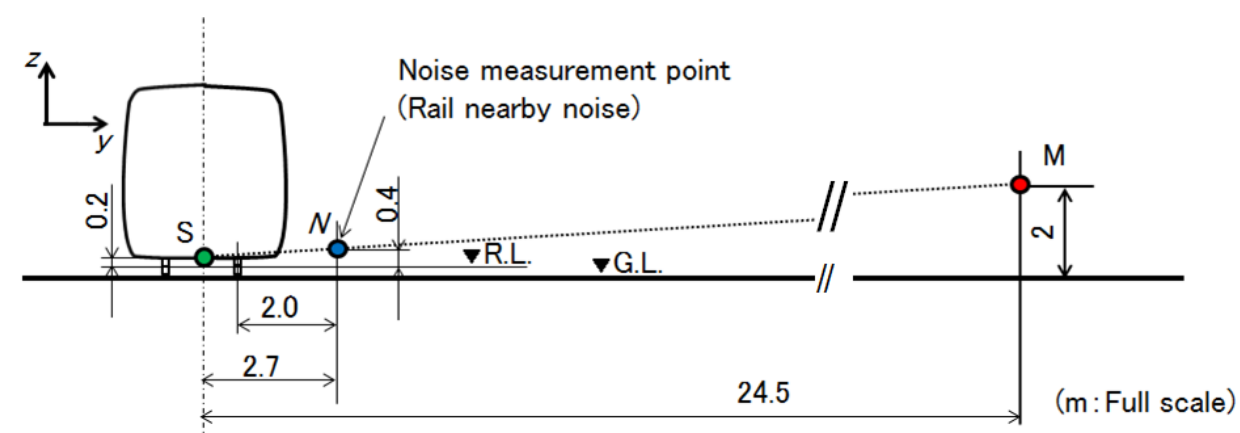

Fig. 10 Noise measurement positions at the wayside of the train track.

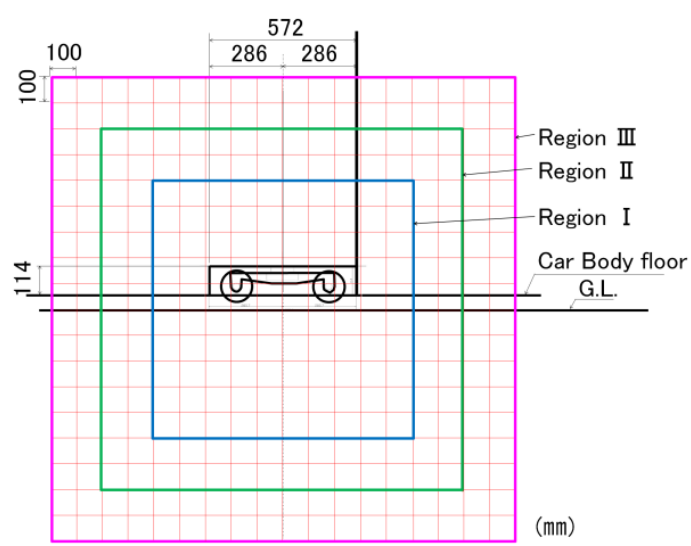

Fig. 11 Grids around the bogie section for the beam forming by 2-D microphone array.

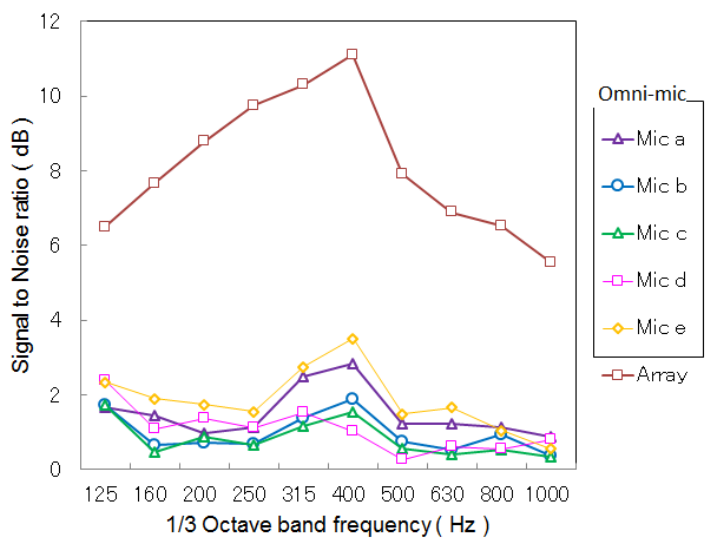

Fig. 12 Difference in the SPL between the Case A and Case D in the middle car condition. Sufficient SNR can be obtained by using microphone array. 
Yamazaki, Kitagawa, Uda, Kurita, Wakabayashi and Nishiura,

Transactions of the JSME (in Japanese), Vol.83, No.851 (2017)

Table 2 Analysis conditions of beam forming.

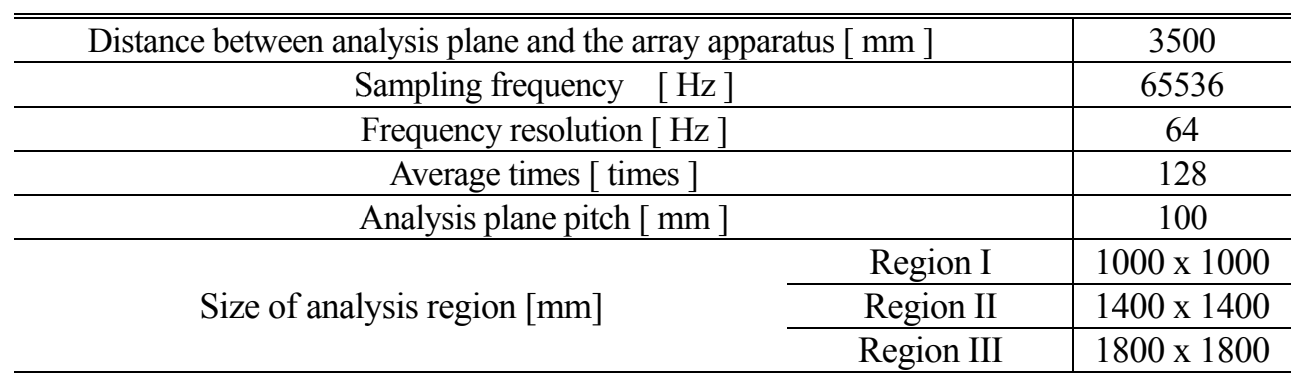

1975 ). この時の主流内の流速は, 図 9 の結果から風洞測定点 S-W8 における流速值を用いた. 式（4）で積分計 算を行う領域 S については，その面積が推定結果に影響を与える可能性があるため，図 11 に示す通り地面によ る反射音の影響を含めた $1000 \mathrm{~mm}$ x $1000 \mathrm{~mm}, 1400 \mathrm{~mm}$ x $1400 \mathrm{~mm}$ および $1800 \mathrm{~mm}$ x $1800 \mathrm{~mm}$ とた条件について 調べた。

\section{$3 \cdot 4$ アレイ装置による測定精度の改善}

一般に用いられている無指向性マイクロホンに対し，アレイ装置を活用することによる S/N の改善度について 検証する．中間車での流速分布を模擬した条件下における台車条件 Aおよび台車条件 D (暗騒音) での音圧レべ ル差 (以下, 信号対雑音比)について, アレイ装置ならびに無指向性マイクロホンによる測定結果を図 12 に示す. 無指向性マイクロホンではほぼすべての周波数帯で信号対雑音比が $3 \mathrm{~dB}$ 以下である.これは測定対象となる台 車部空力音に比べて，それ以外の暗騒音のパワーの方が大きいことを示しており，定量評価を行う上で十分 な測定精度が確保できていない.これに対しアレイ装置による推定結果では全周波数帯域で $4 \mathrm{~dB}$ 以上の信号対雑 音比が確保されている. よって台車部空力音の定量的評価のためには無指向性マイクロホンではなくアレイ装置 を用いた評価が必要であるといえる. 次に中間車での流速分布を模擬した条件下における台車条件 Aについて, 解析領域 S の大きさが台車部空力音の推定結果に与える影響を図 13 に示す。これより Region I Region III での 推定結果の差は $0.2 \mathrm{~dB}$ 以下と十分に小さいことから，以後の解析領域として Region I を用いた結果を用いる. 音 圧レベル分布から無指向性マイクロホンへの換算係数 $C$ の周波数特性を図 14 に示す. 換算係数 $C$ は周波数が低 いほど係数が大きくなる傾向を示す。これはアレイ装置の特性により周波数特性のメインローブの幅が大きくな るためである。

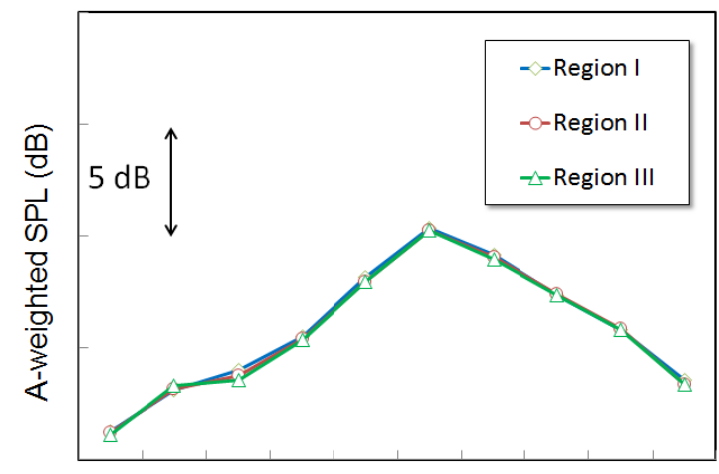

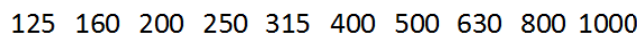
$1 / 3$ Octave band frequency $(\mathrm{Hz})$

Fig. 13 Effect of the analysis region on the estimated aerodynamic bogie noise, $L_{e s t, F}$. Noise level is constant for any cases shown in Fig. 11.

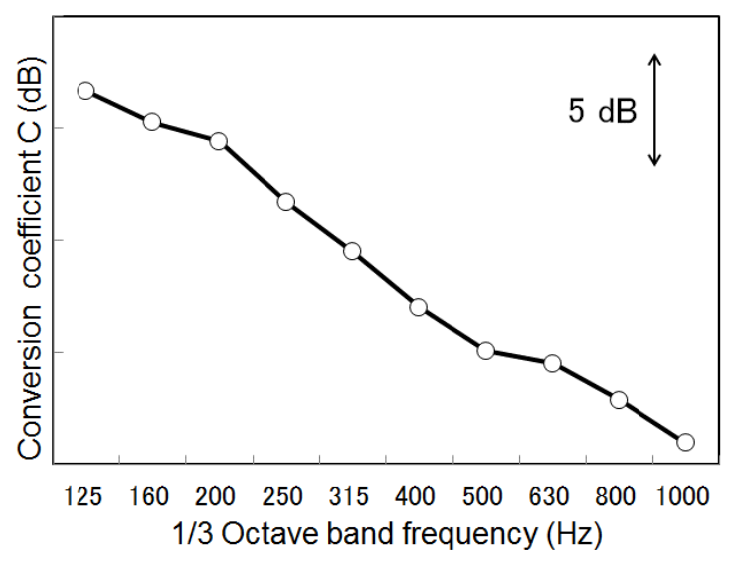

Fig. 14 Conversion coefficient from integrated SPL to the ordinal SPL. 


\section{$3 \cdot 5$ 風洞試験による台車部空力音の推定結果}

風洞試験により得られた先頭車および中間車における条件 A での台車部空力音の周波数特性を図 15 に示す. いずれの周波数帯においても中間車での台車部空力音の推定值は先頭車の場合に比べて約 $4 \mathrm{~dB}$ 小さくなる.この 音圧レベル差が生じる要因を図 9 に示す流速分布特性から考察する. 先頭車と中間車での平均流速の差はまくら ぎ方向位置によって異なり，車両中心付近あるいは車両端部付近では先頭車で無次元流速が約 $0.1 \sim 0.2$ 大きくな るのに対し，レール付近ではほぼ同程度となる。そこで図 9 に示寸風洞試験で得られた全測定点 $(\mathrm{S}-\mathrm{W} 1 \sim \mathrm{S}-\mathrm{W} 8)$ での流速の平均值を代表流速とした場合について，空力音のパワーが流速の 6 乗に比例するという前提のもとに 音圧レベル差を推定する.この場合先頭車と中間車の台車部空力音の音圧レベル差は $60 \log _{10}(0.74 / 0.65)=3.4 \mathrm{~dB}$ と 見積もられる．よって図 15 に示寸音圧レベル差は妥当であると考えられる.

中間車における台車部空力音について, 台車部の側カバー形状を変化させた場合の影響を図 16 に示す. 側力バ 一無の条件 C に対し，側カバーの設置により音圧レベルが低減し，フル側カバーを取り付けることによる低減量 は $125 \mathrm{~Hz}$ 帯〜 $800 \mathrm{~Hz}$ 帯において3〜 $5 \mathrm{~dB}$ である.つまり中間車におけるフル側カバー搭載条件（台車条件 A) 下 での台車部空力騷音は, 図 15 で示すように先頭車に比べて流入速度が低減していることや, 側カバーによる遮音 効果により大きく低減する，このことからも，低騒音対策が施されたフルカバー搭載型の台車部から発生する空 力音を評価するにあたっては，流れ場や台車部側力バ一等の影響を精緻に模擬する必要があると言える.

\section{$3 \cdot 6$ 現地試験による新幹線車両下部音の推定}

風洞試験による中間車流れ場での台車部空力音の推定結果をもとに, 現地試験のレール近傍点で測定された $\mathrm{A}$ 特性音圧レベル（以下，レール近傍騷音）により新幹線車両下部音を推定する. 騒音測定を対象とした現地試験 での解析車両は，2 章で示した流速分布を測定した $\mathrm{A}$ 系車両と車両長，車体幅および床下構造がほぼ同一である 形式（以下， B 系車両）を対象とした。 なお B 系車両の台車装置には図 2 に示寸軸箱部の突起がとりつけられて いないため, 比較対象とする風洞試験による推定結果として, 条件 $\mathrm{A}$ の台車装置から突起を取り外した場合の測 定を用いる.レール近傍騒音レベルの算出に際しては, レール近傍測定点において車両通過時に観測された時間 重み付け特性Fでの音圧レベルの時間波形に対し, 先頭車および先頭から 5-6両目の車間部が通過する際の $150 \mathrm{~ms}$ 間（列車速度 $320 \mathrm{~km} / \mathrm{h}$ 時の走行距離 約 $13 \mathrm{~m}$ ) の平均音圧レベルを求めたうえで，4列車分のパワー平均值を算 出した．なお新幹線の車両下部音には空力音以外の音も含まれると考えられる．そこで同じく 4 列車分のレール 振動等の実測結果から TWINS モデル(北川他, 2013 )により推定した転動音ならびに車両機器音の成分を加えた. 車両下部音の推定結果と実測結果の比較を図 17 に示寸.この結果から $125 \mathrm{~Hz}$ 帯 $1 \mathrm{kHz}$ 帯で車両下部音の推定値 と実測值とが概ね $3 \mathrm{~dB}$ の範囲内で一致している. 特に $315 \mathrm{~Hz}$ 帯 $500 \mathrm{~Hz}$ 帯では台車部空力音の推定值とレール

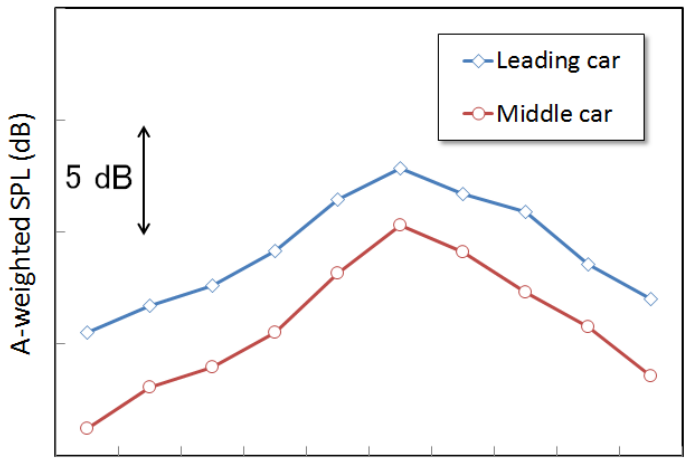

1251602002503154005006308001000 $1 / 3$ Octave band frequency $(\mathrm{Hz})$

Fig. 15 Estimated aerodynamic bogie noise, $L_{e s t, F}$, of case A under leading and middle car conditions. SPL in the middle car condition is lower than that in the leading car condition by about $4 \mathrm{~dB}$.

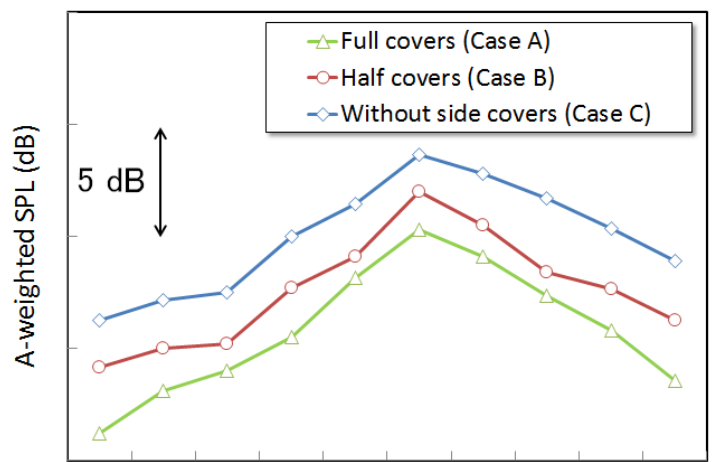

1251602002503154005006308001000 $1 / 3$ Octave band frequency $(\mathrm{Hz})$

Fig. 16 Effect of the side covers of the bogie section under middle car conditions on the estimated aerodynamic bogie noise, $L_{\text {est }, F}$. The aerodynamic bogie noise reduces approximately $3-5 \mathrm{~dB}$ due to the full side covers. 


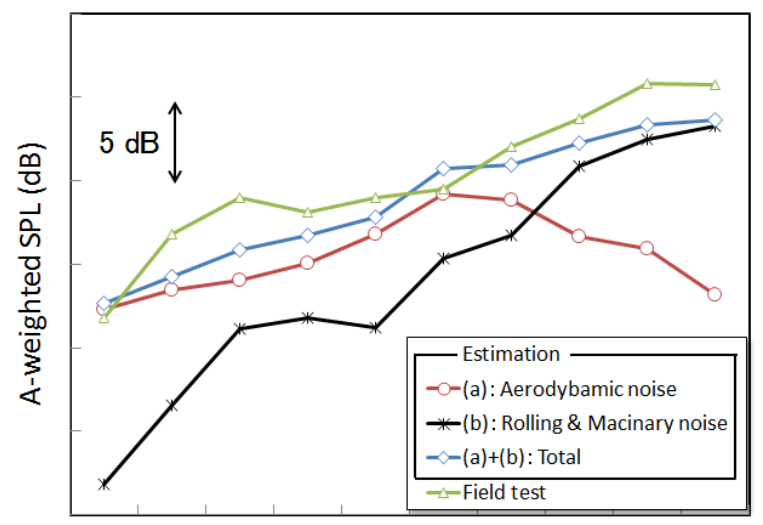

1251602002503154005006308001000

$1 / 3$ Octave band frequency $(\mathrm{Hz})$

Fig. 17 Comparison of the under car noise under the middle car condition obtained in the wind tunnel test with those in the field test. The under car noise is estimated by the aerodynamic noise obtained by the wind tunnel test and the rolling noise calculated by the TWINS model.

近傍騒音レベルがほぼ同レベルとなる.また風洞試験での推定結果から，車両下部音の中で特に $125 \mathrm{~Hz} \sim 500 \mathrm{~Hz}$ 帯の比較的低い周波数成分においては転動音等に比べて台車部空力音の寄与が大きいと言える.

\section{4. 結誩}

高速で走行する新幹線車両から発生する車両下部音のうち，台車部空力音の寄与を評価するための風洞試験法 を開発した．台車部に流入するレール方向の流速成分について，傾向が異なる先頭車と 5 両目台車部でのまくら ぎ方向分布を風洞試験で模擬する方法を提案した。 また，台車部空力音を精度よく測定するため，台車部まわり の二次元音圧レベル分布を測定したうえで，車両側方における騒音レベルに変換する手法を提案した．得られた 主な知見は以下の通りである.

(1) 車両下部に設置した部材の後流域, ならびに風洞のノズルまわりに生成される自由せん断層内の速度欠損領 域を利用して台車部流入速度のまくらぎ方向分布を調整する手法を提案し，それぞれの手法で先頭車ならび に中間車台車部流入速度分布が再現できることを示した.

(2) 本提案手法により推定された台車部空力音ならびにレール振動等から推定された車両下部音と，現地のレー ル近傍で測定された車両下部音を比較した結果，中間車両での車両下部音について，125Hz 帯〜 $1 \mathrm{kHz}$ 帯で推 定車両下部音と実測值とが概ね $3 \mathrm{~dB}$ の範囲内で一致していることを示した.

（3）風洞試験での推定結果から，車両下部音の中で $125 \mathrm{~Hz} \sim 500 \mathrm{~Hz}$ 帯の比較的低い周波数成分については，転 動音等に比べて台車部空力音の寄与が大きいことを示した.

なお，空力音の発生は流れ場の乱れ度と密接に関連している．また台車キャビティ内部で発生した騒音が車両 側方の観測点に至る過程では，台車キャビティ部の内壁や地面での反射，および側力バーでの遮へいの影響を受 ける．これらの点をふまえ，今後は台車部空力音と流れ場との関係の調査ならびに騒音の伝播特性についての検 討を行っていく予定である.

\section{文献}

Amiet, R. K., Correction of open jet wind tunnel measurements for shear layer refraction, 2nd AIAA Aeroacousitcs Conference, Paper No. 75-532 (1975).

Flanagan, J. L., Johnston, J. D., Zahn, R. and Elko, G. W., Computer-steered microphone arrays for sound transduction in large rooms. Journal of the Acoustical Society of America, Vol. 78, No. 5 (1985), pp. 1508-1518.

岩㟝 誠, 井門 敦志, 山崎 展博, 宇田 東樹, 若林 雄介, 新幹線車両の床下流れの特性, 鉄道総研報告, Vol.29, No.5 (2015), pp.11-16.

Kitagawa, T. and Nagakura, K., Aerodynamic noise generated by Shinkansen cars, Journal of Sound and Vibration, Vol.231, No.3 (2000), pp.913-924. 
北川敏樹，長倉清，栗田健，高速走行時における車両下部音の音源別寄与度，鉄道総研報告，Vol.27, No.1 (2013), pp.23-28.

Kurita, T., Wakabayashi, Y., Yamada, H. and Horiuchi, M., Reduction of wayside noise from Shinkansen high-speed trains, Journal of Mechanical Systems for Transportation and Logistics, Vol.4, No.1 (2011), pp.1-11.

Kurita, T., Development of external-noise reduction Technologies for Shinkansen high-speed trains, Journal of Environment and Engineering, Vol.6, No.4 (2011), pp.805-819.

Mueller, T. J., Aeroacoustic measurements, Springer (2002), pp.83-86.

森田 潔, 茂山 正明, 北山 茂, 隅田 一也, 数值解析による車両台車部空力騒音の可視化, 環境工学総合シンポジ ウム講演論文集 (2006), pp.118-121.

Masson, E., Paradot, N. and Allain, E., The Numerical prediction of the aerodynamic noise of the TGV POS high-speed train power car, Noise and Vibration Mitigation for rail Transportation Systems (2011), pp. 437-444, Springer.

Mellet, C., Létourneaux, F., Poisson, F. and Talotte, C., High speed train noise emission: Latest investigation of the aerodynamic/rolling noise contribution, Journal of Sound and Vibration, Vol. 293, Issues 3-5, 13 (2006), pp. 535-546.

長倉 清, 善田 康雄, 新幹線騒音の音源解析法, 鉄道総研報告, Vol.10, No.2 (1996), pp. 29-33.

Poisson, F., Gautier, P. E. and Letourneaux, F., Noise sources for high speed trains: A Review of Results in the TGV Case, Noise and Vibration Mitigation for Rail Transportation Systems,Vol. 99 (2008), pp. 71-77, Springer.

Thompson, D. J., Iglesias, E. L., Liu, X., Zhu, J. and Hu, Z., Recent developments in the prediction and control of aerodynamic noise from high-speed trains, International Journal of Rail Transportatio, Vol.3, Issue 3(2015), pp. 119-150.

宇田 東樹, 若林 雄介, 栗田 健, 岩㠃 誠, 山崎 展博, 井門 敦志, スラブ軌道区間における新幹線車両下部の流 速分布，日本機械学会論文集, Vol.81, No.830 (2015), DOI:10.1299/transjsme.15-00161.

横山 博史, 加藤 千幸, 乱流境界層内のキャビティ音発生におけるフィードバック機構: 第 1 報, 流体力学的振 動 (流体工学, 流体機械), 日本機械学会論文集 B 編, Vol.75, No.760 (2009), pp.2369-2378.

\section{References}

Amiet, R. K., Correction of open jet wind tunnel measurements for shear layer refraction, 2nd AIAA Aeroacousitcs Conference, Paper No. 75-532 (1975).

Flanagan, J. L., Johnston, J. D., Zahn, R. and Elko, G. W., Computer-steered microphone arrays for sound transduction in large rooms. Journal of the Acoustical Society of America, Vol. 78, No. 5 (1985), pp. 1508-1518.

Iwasaki, M., Ido, A., Yamazaki, N., Uda, T. and Wakabayashi, Y., Characteristics of under-floor flow of Shinkansen vehicle, RTRI report, Vol.29, No.5 (2015), pp. 11-16 (in Japanese).

Kitagawa, T. and Nagakura, K., Aerodynamic noise generated by Shinkansen cars, Journal of Sound and Vibration, Vol.231, No.3 (2000), pp.913-924.

Kitagawa, T., Nagakura, K. and Kurita, T., Contribution of rolling noise and aerodynamic noise to the total noise generated from the lower part of Shinkansen cars running at high-speed, RTRI report, Vol.27, No.1 (2013), pp.23-28 (in Japanese).

Kurita, T., Wakabayashi, Y., Yamada, H. and Horiuchi, M., Reduction of wayside noise from Shinkansen high-speed trains, Journal of Mechanical Systems for Transportation and Logistics, Vol.4, No.1 (2011), pp.1-11.

Kurita, T., Development of external-noise reduction technologies for Shinkansen high-speed trains, Journal of Environment and Engineering, Vol.6, No.4 (2011), pp.805-819.

Mueller, T. J., Aeroacoustic measurements, Springer (2002), pp.83-86.

Morita, K., Shigeyama, M., Kitayama, S. and Sumita, K., Visualization of aeroacoustic sound sources of bogie section for high speed trains, Symposium on Environmental Engineering, Paper No. 127 (2006), pp. 118-121 (in Japanese).

Masson, E., Paradot, N. and Allain, E., The Numerical prediction of the aerodynamic noise of the TGV POS high-speed rain power car, Noise and Vibration Mitigation for rail Transportation Systems (2011), pp.437-444, Springer.

Mellet, C., Létourneaux, F., Poisson, F. and Talotte, C., High speed train noise emission: Latest investigation of the aerodynamic/rolling noise contribution, Journal of Sound and Vibration, Vol. 293, Issues 3-5 (2006), pp. 535-546.

Nagakura, K. and Zenda, Y., The Methods of analyzing Shinkansen noise, RTRI report, Vol.10, No.2 (1996), pp.29-33 (in Japanese).

Poisson, F., Gautier, P. E. and Letourneaux, F., Noise sources for high speed trains: A Review of Results in the TGV Case, Noise and Vibration Mitigation for Rail Transportation Systems, Vol. 99 (2008), pp. 71-77, Springer. 
Yamazaki, Kitagawa, Uda, Kurita, Wakabayashi and Nishiura,

Transactions of the JSME (in Japanese), Vol.83, No.851 (2017)

Thompson, D. J., Iglesias, E. L., Liu, X., Zhu, J. and Hu, Z., Recent developments in the prediction and control of aerodynamic noise from high-speed trains, International Journal of Rail Transportation, Vol.3, Issue 3 (2015), pp. 119-150.

Uda, T., Wakabayashi, Y., Kurita, T., Iwasaki, M., Yamazaki, N. and Ido, A., Velocity profile under Shinkansen vehicle on slab track, Transactions of the JSME (in Japanese), Vol.81, No.830 (2015), DOI:10.1299/transjsme.15-00161.

Yokoyama, H. and Kato, C., Fluid-acoustic interactions in acoustic radiation in turbulent cavity flows : fluid-dynamic oscillations, Transactions of the Japan Society of Mechanical Engineers, Series B, Vol.75, No.760 (2009), pp.2369-2378 (in Japanese). 